\title{
Evaluation of self-etching primer on bond strength in feldspathic ceramic
}

\author{
Avaliação do primer auto condicionante na resistência de união em cerâmica feldspática \\ Evaluación de el primer autograbante sobre la fuerza de unión en cerámica feldespática
}

Received: 04/01/2021 | Reviewed: 04/16/2021 | Accept: 04/24/2021 | Published: 05/09/2021

\author{
Nathalia Eduardo Sgrott \\ ORCID: https://orcid.org/0000-0001-6375-0931 \\ Faculdade São Leopoldo Mandic, Brazil \\ E-mail: naasgrott@gmail.com \\ Renata Bahia Accioly \\ ORCID: https://orcid.org/0000-0001-8030-6170 \\ Faculdade São Leopoldo Mandic, Brazil \\ E-mail: dra.renataaccioly@gmail.com \\ Isaias Donizeti Silva \\ ORCID: https://orcid.org/0000-0001-6335-7785 \\ Universidade Santo Amaro, Brazil \\ E-mail: isaiasdonizeti@gmail.com \\ Laura Soares Souto Lepesqueur \\ ORCID: https://orcid.org/0000-0001-8584-885X \\ Universidade Santo Amaro, Brazil \\ E-mail: lalepesqueur@hotmail.com \\ Karina Andrea Novaes Olivieri \\ ORCID: https://orcid.org/0000-0001-8843-8901 \\ Faculdade São Leopoldo Mandic, Brazil \\ E-mail: karina.olivieri@ slmandic.edu.br \\ William Cunha Brandt \\ ORCID: https://orcid.org/0000-0002-6362-0499 \\ Universidade Santo Amaro, Brazil \\ E-mail: wcbrandt@prof.unisa.br
}

\begin{abstract}
The aim of the study was to evaluate the effect of self-etching silane primer on long-term bonding strength on feldspathic ceramic. Ceramic blocks (IPS Empress CAD, Ivoclar Vivadent) were cut with a low-speed diamond disk (Isomet 1000, Buehler) into 40 blocks of $12 \times 7 \times 6 \mathrm{~mm}$, under water cooling, and randomly divided into two groups $(\mathrm{n}=20)$, according to the surface conditioning: hydrofluoric acid (HF) (Condac, FGM) or self-etching silane primer (MEP) (Monobond Etch and Prime, Ivoclar Vivadent). After the blocks were bonded to composite resin blocks (12 x 7 x 3mm) (Liss, FGM) with a light cured cement (Variolink Esthetic LC, Ivoclar Vivadent) and LED photoactivation (Radii Cal, SDI) for $40 \mathrm{~s}$ on each luting interface line. The sets were cut in sticks with 1-mm 2 cross-section composed of ceramic/cement/composite and tested after $24 \mathrm{~h}$ (baseline) and 90 days aging by stored in distilled water at $37^{\circ} \mathrm{C}$. Microtensile bond strength testing ( $\mu \mathrm{TBS}$ ) was performed using a universal machine (DL-1000, EMIC) submitted to traction with speed of $0.5 \mathrm{~mm} / \mathrm{min}$ until rupture of adhesion. Fracture of specimens were examined under stereomicroscopy to determine the failure pattern. Bond strength (MPa) was calculated, and the failure pattern and interface topography were assessed using scanning electron microscopy (SEM). No significant different $\mu$ TBS was observed between groups HF and MEP ( $p>0.05$ ). Storage time of the samples did not affect the $\mu$ TBS from the groups. Surface etching pattern with HF produced higher surface alterations than a self-etching primer. Application of MEP may be considered an alternative for silanization for feldspathic ceramic.
\end{abstract}

Keywords: Ceramics; Hydrofluoric acid; Aging; Topography; Adhesiveness.

\section{Resumo}

O objetivo no estudo foi avaliar o efeito de um primer de silano auto condicionante na resistência de união a longo prazo em cerâmica feldspática. Os blocos cerâmicos (IPS Empress CAD, Ivoclar Vivadent) foram cortados com um disco de diamante em baixa velocidade (Isomet 1000, Buehler) em 40 blocos de 12x7x6mm, sob refrigeração e divididos aleatoriamente $(n=20)$, de acordo com o condicionamento da superfície: ácido fluorídrico (HF) (Condac, FGM) e auto condicionante (MEP) (Monobond Etch and Prime, Ivoclar Vivadent). Foram cimentados (Variolink Esthetic LC, Ivoclar Vivadent) blocos de resina composta (12x7x3mm) (Liss, FGM) e fotoativação (Radii Cal, SDI) por 40 segundos em cada interface de cimentação. Os conjuntos foram cortados para obtenção das amostras com seção transversal de $1 \mathrm{~mm} 2$ (cerâmica/cimento/compósito) e testado após $24 \mathrm{~h}$ e 90 dias de após o envelhecimento por armazenamento em água destilada a $37^{\circ} \mathrm{C}$. O ensaio de microtração ( $\mu \mathrm{TBS}$ ) foi realizado em máquina universal (DL1000, EMIC) submetida à tração com velocidade de $0,5 \mathrm{~mm} / \mathrm{min}$ até a ruptura da união. A fratura dos espécimes foi 
examinada sob estereomicroscopia para determinar o padrão de falha. Foram obtidas a força de união (MPa), o padrão de falha e a topografia por meio de microscopia eletrônica de varredura. Não foi observada diferença significativa nos valores de $\mu$ TBS entre os grupos HF e MPE ( $p>0,05$ ). O tempo de armazenamento das amostras não alterou os valores de $\mu$ TBS. No entanto o condicionamento com HF produziu maiores alterações de superfície da cerâmica do que o silano auto condicionante. Baseados nos dados obtidos o MPE pode ser considerado uma alternativa para silanização de cerâmica feldspática.

Palavras-chave: Cerâmica; Ácido fluorídrico; Envelhecimento; Topografia; Adesividade.

\section{Resumen}

El objetivo em esto estudio fue evaluar el efecto el primer de la imprimación de silano autograbante sobre la resistencia de la unión a largo plazo en cerámica de feldespato. Los bloques cerámicos (IPS Empress CAD, Ivoclar Vivadent) se cortaron con un disco de diamante de baja velocidad (Isomet 1000, Buehler) en 40 bloques de $12 \times 7 \times 6 \mathrm{~mm}$, bajo refrigeración y divididos aleatoriamente $(\mathrm{n}=20)$, según el acondicionamiento de la superficie: ácido fluorhídrico (HF) (Condac,FGM) y autograbante (MEP) (Monobond Etch and Prime, Ivoclar Vivadent). Se cementaron (Variolink Esthetic LC, Ivoclar Vivadent) bloques de resina compuesta (12 x 7 × 3 mm) (Liss, FGM) y fotoactivación (Radii Cal, SDI) durante 40 segundos en cada interfaz de cementación. Los conjuntos se cortaron para obtener muestras con una sección transversal de $1 \mathrm{~mm} 2$ (cerámica/cemento/composite) y se ensayaron a las $24 \mathrm{~h}$ y 90 días después del envejecimiento mediante almacenamiento en agua destilada a $37^{\circ} \mathrm{C}$. La prueba de microtensión ( $\mu$ TBS) se realizó en una máquina universal (DL-1000, EMIC) a tracción con una velocidad de 0,5 $\mathrm{mm} / \mathrm{min}$. La fractura de las muestras se examinó bajo estereoscopía para determinar el patrón de falla. La fuerza de unión (MPa), el patrón de falla y la topografía se obtuvieron mediante microscopía electrónica de barrido. No hubo diferencia significativa en los valores de $\mu$ TBS entre los grupos HF y MPE ( $p>0.05$ ). El tiempo de almacenamiento de las muestras no cambió los valores de $\mu$ TBS. Sin embargo, el acondicionamiento con HF produjo cambios importantes en la superficie cerâmica que el silano autograbante. Con base en los datos obtenidos, el MPE puede ser una alternativa para la silanización de cerámicas feldespáticas.

Palabras clave: Cerámica; Ácido fluorhídrico; Envejecimiento; Topografía; Adhesividad.

\section{Introduction}

Ceramic has been indicated as an indirect restorative material in Dentistry, considering adequate mechanical properties, biocompatibility and esthetic properties (Choi, Kang, \& Att, 2020; Kim, Choi, Kang, \& Att, 2021; Sen \& Us, 2018). In addition, feldspathic (Fd) computer-aided design and computer-aided manufacturing (CAD-CAM) has offered the advantage of automatized technology and standardized methods, which provides process controlling, improving predictability, and less operator influence (Kollmuss, Kist, Goeke, Hickel, \& Huth, 2016; Ritzberger, Schweiger, \& Höland, 2016; Tribst et al., 2018). IPS Empress CAD system is composed of a silica-rich phase (Gracis, Thompson, Ferencz, Silva, \& Bonfante, 2015) that is reinforced with crystalline content to improve mechanical properties (Ritzberger et al., 2016). This material is indicated for making anterior and posterior inlays, onlays, veneers, single crowns, presenting an excellent esthetic performance and flexural resistance (Gracis et al., 2015; Ritzberger et al., 2016).

Conventionally the gold standard protocol for surface treatment to glass-matrix ceramics is considered by a response of the material to hydrofluoric acid (HF) exposure. HF etching in glass-ceramic materials may act on material components, dissolving the glass-matrix ceramic and improving roughness patterns on the surface, improving the micro-retention for adhesion to resin cement (Choi et al., 2020; Gracis et al., 2015; Murillo-Gómez, Palma-Dibb, \& De Goes, 2018; Ramakrishnaiah, Alkheraif, Divakar, Matinlinna, \& Vallittu, 2016). Also, the surface treatment includes the hydroxyl groups that have high interaction with silane-coupling agents (Özcan \& Volpato, 2015). Silane is a bifunctional molecule that produces the chemical interaction between the silica from the ceramic and methacrylate groups of resin monomers. Thus, the silanization acts on the interaction between ceramic and composite resin-based composite surfaces, bonding both chemically by siloxane bonds (Lung \& Matinlinna, 2012; Naves et al., 2010).

Self-etching materials have been introduced to surface treatment of glass-ceramic materials to simplify the clinical steps of treatment by etching and silanization process and is considered a safer procedure rather than the application of HF (Cardenas et al., 2019; Lopes, Perdigão, Baptista, \& Ballarin, 2019; Tribst et al., 2018). The manipulation of HF may expose 
the clinicians and patients to potential risks, from acid contact to biological risks of damage to soft tissues (Cardenas et al., 2019; Murillo-Gómez et al., 2018; Tribst et al., 2018). Also, the self-etching silane primer clinical could act on preservation of the glass phase of ceramic materials, improving a mechanical performance and acting on maintenance of adequate adhesion between restorative materials or dental substrate and ceramic restorations (Murillo-Gómez, Palma-Dibb, \& De Goes, 2018).

According to the manufacturer, the self-etching silane primer materials as Monobond Etch and Prime (MEP, Ivoclar Vivadent, Schaan, Liechtenstein), used in this study has in the composition of material ammonium polyfluoride, which replaces the HF etching of surface and trimethoxypropyl methacrylate that acts on silanization (El-Damanhoury \& Gaintantzopoulou, 2018; Murillo-Gómez et al., 2018; Tribst et al., 2018). Thus, according to the manufactures, the self-etching silane primer allows treatment of glass-ceramics without compromising bond strength, although the pattern of surface roughness is smoother than HF etching (Cardenas et al., 2019; Murillo-Gómez et al., 2018; Tribst et al., 2018).

Besides that, the bonded interface is affected by water degradation in the long-term (Lung \& Matinlinna, 2012; Murillo-Gómez et al., 2018). However, only a few studies have evaluated the behavior of bonded interface integrity and the bond strength between resin cement and glass-matrix ceramic conditioning with self-etching primer submitted to aging. Thus, the purpose of this in vitro study was to bond CAD-CAM glass-ceramics to a resin cement by self-etching primer or conventional HF etching followed by silanization. The null hypothesis tested was that no significant differences would be found on the bond strength produced by the surface treatments tested among the specimens stored in water for $24 \mathrm{~h}$ or 3 months of water storage.

\section{Methodology}

\subsection{Specimen preparation}

Blocks of ceramic (IPS Empress CAD, Ivoclar Vivadent AG, Schaan, Liechtenstein) were selected, they were cut into a rectangular section using a diamond disk at low speed (250rpm) (Buehler, IsoMet, Lake Bluff, IL, USA) under water cooling, totaling forty blocks $(12 \times 7 \times 6 \mathrm{~mm})$. Blocks surfaces were polished with decreasing granulation paper $(600,800$, and 1200 grit; 3M; St Paul, MN, USA) using a polish machine (Aropol 2V-PU, Arotec, Cotia, SP, Brazil) under water cooling. After, the specimens were cleaning ultrasonically (Ultrasonic cleaner, Cristofóli, Campo Mourão, PR, Brazil) with distilled water for $5 \mathrm{~min}$ and dried by air jet. Specimens were crystallized following the program recommended by the manufacturer.

Composite blocks (Llis, FGM, Joinville, SC, Brazil) were prepared by a metal matrix with a dimension of 12x7x3mm. They were prepared using the layering technique (maximum 2-mm-thick layers) and polymerized for $40 \mathrm{~s}$ (Radii-Cal, SDI, Bayswater, Victoria, Australia). Composite blocks were prepared with 37\% phosphoric acid for 60 seconds and were cleaned ultrasonically (Ultrasonic cleaner, Cristofóli, Campo Mourão, PR, Brazil) with distilled water for $5 \mathrm{~min}$ and air dried for $30 \mathrm{~s}$. Then, the adhesive was applied on the surface for $30 \mathrm{~s}$ and dried for volatilization of the solvent.

\subsection{Experimental design}

Blocks were randomly divided into two groups $(n=20)$ according to the silanization procedure $(\mathrm{HF}+\mathrm{Silane}$ or Monobond Etch and Prime, Ivoclar Vivadent AG, Schaan, Liechtenstein) and the presence of aging by stored water for 24h (b - baseline) and for 90 days (a-aging). Prior to the conventional silanization technique (HF), blocks were etched with 10\% hydrofluoric acid (Condacporcelana, FGM, Joinville, SC, Brazil) for 60 seconds, rinsed with water for the same time, and dried with an oil-free air jet. Monobond Plus silane was applied on the surface for 60 seconds, and dried for volatilization of the solvent. For the group with the self-etching primer (MEP), MEP was applied with scrubbing for 20 seconds and left to react for 40 seconds, then the blocks were rinsed with water for the same time, and dried. 


\subsection{Microtensile Bond Strength Test ( $\mu$ TSB)}

The procedure of luting was performed after preparation of composite and ceramic blocks as described before. A single operator performed all the bonding procedures. Resin composite blocks were luted with a light cured resin cement (Variolink Esthetic LC, Ivoclar Vivadent AG, Schaan, Liechtenstein) and positioned over the ceramic blocks and kept in position using a device with 45,8 $\mathrm{g}$ weight for 5 minutes, after the excess of cement was removed. Simultaneously, the photoactivation was performed the for 40s on each line and luting of the set cement-resin-ceramic, using a LED (Radii Cal, Bayswater, Victoria, Australia) light curing having a irradiance power density of $1200 \mathrm{~mW} / \mathrm{cm}^{2}$. The set composite-cementceramic was cut using a double-sided $152 \times 0.5 \mathrm{~mm}$ (LC diamond wafering Blades Buehler, Lake Bluff, IL, USA) diamond disk, under water cooling, into $1-\mathrm{mm}^{2}$ cross-section beams composed of ceramic/cement/composite. Sticks were stored in Eppendorf tube with distilled water at $37^{\circ} \mathrm{C}, \mathrm{pH} 6,0$ for $24 \mathrm{~h}$ to baseline group (b) and for 90 days for aging group (a), the water was changed every 30 days.

Before the evaluation of the microtensile bond strength, each specimen was measured with a digital caliper (Mitutoyo Corporation, Japan), to calculate the dimension of the adhesion interface, to determine the bond strength (MPa) that was calculated by dividing the load at failure $(\mathrm{N})$ by the adhesive area $\left(\mathrm{mm}^{2}\right)$.

Each specimen was glued with cyanoacrylate adhesive (Loctite Super Bonder,Henkel, Itapevi, SP, Brazil) on the microtensile bond strength test device. Microtensile test was performed in a universal machine (Model DL-1000, EMICEquipment and Systems-Ltd, São José dos Pinhas, PR, Brazil) with a load cell of 20KgF and submitted to traction with speed of $0.5 \mathrm{~mm} / \mathrm{min}$ until the failure of the bonding. Also, the fractured specimens were examined under stereomicroscope (ZEISS MC 80 DX) to determine the failure pattern. Failure modes were classified according to the failure, as either a cohesive failure of resin composite or cohesive failure of the ceramic ( $\mathrm{COH}$ res/cer), adhesive failure, which occurred between resin composite/resin cement or between ceramic/resin cement (ADH cer/cim), or mixed adhesive/cohesive failure (MIX) (Prado et al., 2018).

One representative specimen from each group was randomly selected for scanning electron microscopy (SEM) analysis (JSM $5600 \mathrm{LV}, \mathrm{JEOL}$ ) operated at $15 \mathrm{kV}$. After the bond strength tests each sample was coated with gold, creating a $10 \mathrm{~nm}$ of thickness layer (Bal-Tec SCD 050). Besides the analysis of failure, four ceramic samples were prepared following the same protocols of etching cited before, for the evaluation of conditioning pattern, using previous parameters to control the SEM analysis.

\subsection{Statistical Analysis}

Data distribution was analyzed using the Shapiro-Wilk test and then by two-way analysis of variance (ANOVA: silanization method $\mathrm{x}$ aging). Tests were performed with $\alpha=0.05$, using the software SigmaPlot 12.0 (Systat Software Inc., San Jose, CA, USA).

\section{Results}

\subsection{Microtensile Bond Strength Test}

The mean values of microtensile bond are shown in Table 1, values ranged between 19.3 and 24.7 MPa (Table 1). There were no significant differences among the groups (Two-way ANOVA; $p=0.322$ ), which means, no significant difference was observed between the silanization protocols applied $(\mathrm{p}=0.276)$. Also, no difference was found in the bond strength results for the aging factor $(\mathrm{p}=0.122)$. 
Table 1: Mean and standard deviation (SD) of $\mu \mathrm{TBS}$ in (MPa).

\begin{tabular}{lll}
\hline & \multicolumn{2}{l}{ Feldspathic (IPS Empress CAD) } \\
\hline & Conventional & Self-Etching silane primer \\
$($ HF + Silane) & (Monobond Etch and Prime) \\
\hline Baseline (b) & $20.8(8.9)$ & $19.3(10.7)$ \\
\hline Aging (a) & $19.5(5.7)$ & $24.6(9.4)$ \\
\hline
\end{tabular}

Source: Authors (2021).

\subsection{Failure pattern}

The analysis of the type of failure was classified using a stereomicroscope with 50X of magnification (Table 2). Failure classified as mixed (MIX) was predominant in all analyzed groups. However, after 90 days of water storage samples, it was observed a tendency to increase adhesive failures. Despite the low prevalence the cohesive failures were present in all groups.

Table 2: Classification of the type of failure.

\begin{tabular}{llll}
\hline Groups & Adhesive failure & Cohesive failure & Mixed failure \\
& $\%$ & $\%$ & $\%$ \\
\hline HFb & 15 & 14 & 71 \\
\hline HFa & 30 & 3 & 67 \\
\hline MEPb & 22 & 6 & 72 \\
\hline MEPa & 36 & 6 & 58
\end{tabular}

HFb: conventional baseline; HFa: conventional aging; MEPb: self-etching silane primer baseline; MEPa: self-etching primer aging. Source: Authors (2021).

Representative micrographs of failures found on tested samples from SEM analysis (70x magnification) are shown summarized on Figure 1.

Figure 1: Representative scanning electron microscope images regarding failure pattern of 70x to A: adhesive failure; B: cohesive failure; $\mathrm{C}$ : mixed failures.
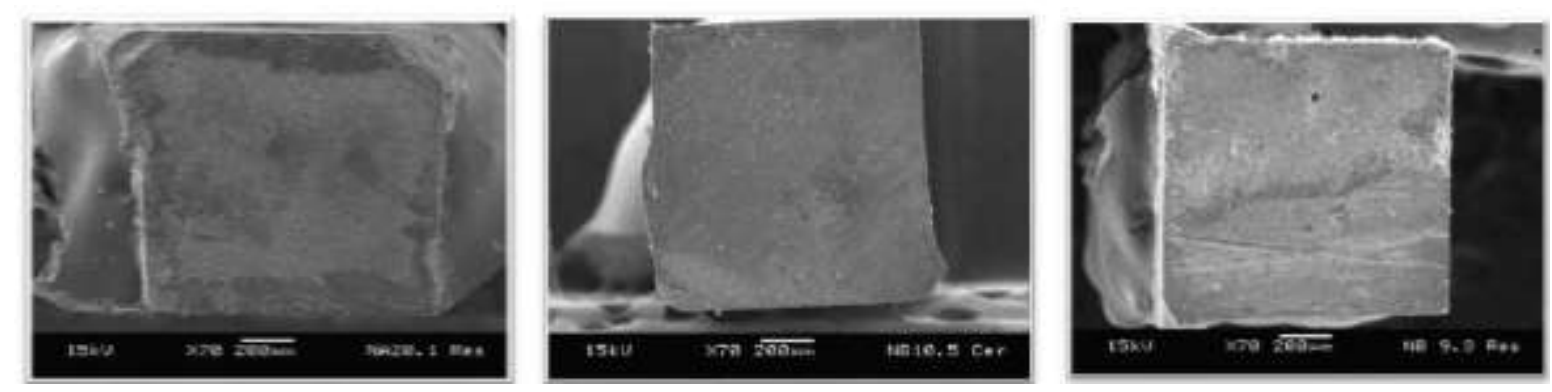

Source: Authors (2021).

Also, representative SEM images (2000X) of ceramic surface after conventional and self-etching silane pattern are shown in Figure 2. Both surfaces showed changes on the surface microstructure, the surface etched with HF for $60 \mathrm{~s}$ showed an irregular surface, roughness, microporosities and deeper pores due to the dissolution of the glass matrix. While self-etching 
primer caused a partial dissolution of the glass matrix, since the specimen showed fewer changes on surface topography with fewer pores and smoother roughness.

Figure 2: Representative scanning electron microscope images of feldspathic ceramic 2000x to ceramic surface conditioning with conventional (A) and self-etching primer (B).

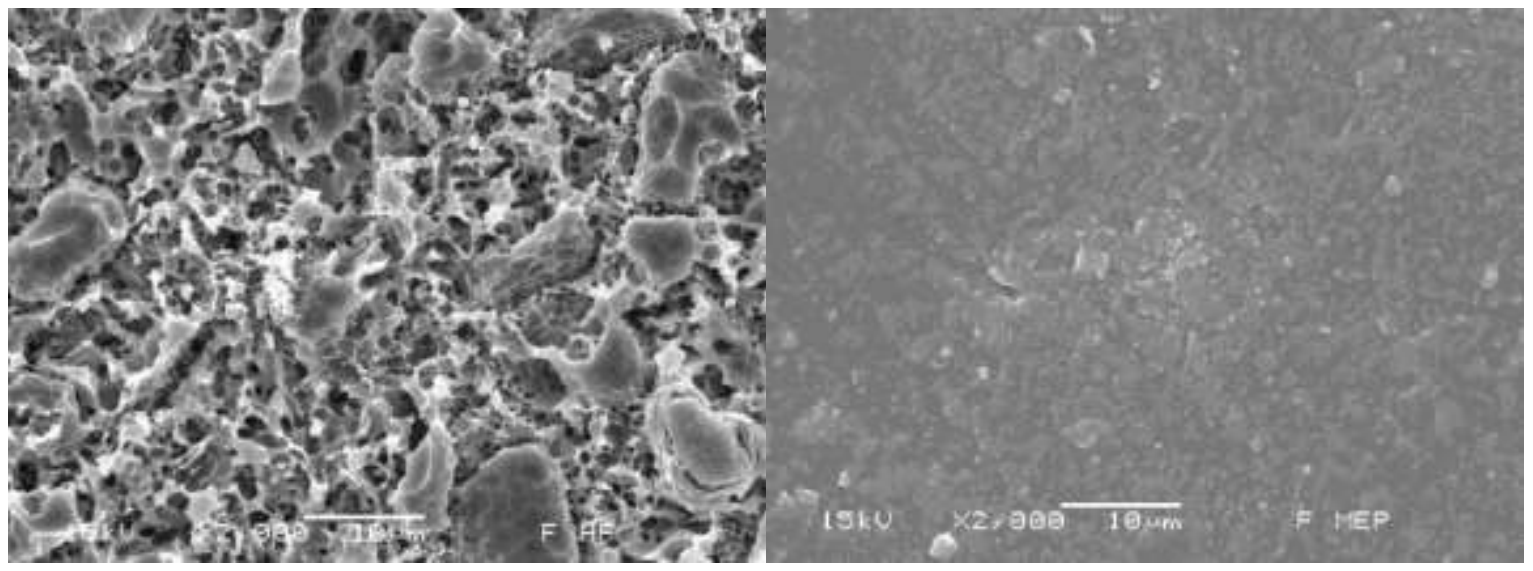

Source: Authors (2021).

\section{Discussion}

Based on the findings of this in vitro study, the null hypothesis that no significant differences on bond strength produced by self-etching silane primer and HF for feldspathic ceramics was accepted.

In this study, the bonding effectiveness promoted by MEP and HF, evaluated by microtensile bond strength test, was considered statically similar, as founded in previous studies (Cardenas et al., 2019; Murillo-Gómez et al., 2018). Although, the conventional method of etching with HF promoted higher surface microporosity, and higher dissolution of the glass matrix when compared with HF. When the HF is applied on the surface of glass ceramic, the tetrafluorosilane is formed, which further reacts with HF to form a soluble hydrofluorosilicic acid. Then the vitreous matrix is dissolved and rinsed away, producing microscopically changes on the surface, increase of the surface energy, roughness and pores (Lung \& Matinlinna, 2012; Tribst et al., 2018).

Even though, etching procedure using HF and silane is still considered the gold standard method for glass ceramic conditioning (El-Damanhoury, N, Sheela, \& Gaintantzopoulou, 2020), promoting high changes on surface topography, which is essential to enhance the micromechanical bonding area, which is not always correlated to high bond strength values for feldspathic ceramic (Murillo-Gómez et al., 2018; Venturini, Prochnow, Rambo, Gundel, \& Valandro, 2015).

Despite the etching pattern of the surface of treatments shown in SEM images, ceramic treated to self-etching ceramic primer showed less dissolution of the glass matrix, considering the use of thin ceramic restorations, the use of self-etching primer ceramic represents a less aggressive alternative to the glass phase preserving the mechanical properties and longevity of restorations (Murillo-Gómez et al., 2018). According to reports of previous studies, higher surface roughness does not impact directly in the bond strength values. Thus, feldspathic ceramic known characteristic can explain the role of chemical interaction supported by the silanization procedure, due to the higher amount of glass matrix (Sinthuprasirt, van Noort, Moorehead, \& Pollington, 2015). Silanization process can act on the adhesion of dissimilar materials. Silane is a bifunctional compound, which can connect to inorganic and organic materials promoting the adhesion between the organic resin part and inorganic material from ceramics (Matinlinna, Lung, \& Tsoi, 2018; Yoshihara et al., 2020). 
Previous reports pointed out that the active application mode of self-etching primer could improve the spreading on the surface of ceramic improving the contact angle and wettability proprieties of the ceramic (Tribst et al., 2018). Also, the use of self-etching ceramic primer may prevent the risks of occupational exposure to HF, due to the potential risks of toxicity and damage to soft tissues (Cardenas et al., 2019; Lopes et al., 2019; Tribst et al., 2018). Therefore, the self-etching primer could be considered as an alternative method to etching of glass ceramics, since it is considered a safer procedure, for enabling the simplification of clinical steps and for its promising performance on bond strength evaluation in this investigation, in agreement to previous evaluations (Cardenas et al., 2019; Murillo-Gómez et al., 2018;).

This investigation found a major prevalence of mixed failures in both treatment, $\mathrm{HF}+$ silane and self-etching primer, the same behavior was found in preliminary investigations (Tribst et al., 2018). It suggests that the silane methacrylate contained in the self-etching primer can generate a chemical bond between the vitreous substrate and resin cement (MurilloGómez \& De Goes, 2019; Murillo-Gómez et al., 2018).

The aging process, by storing the samples for 90 days in water, was not sufficient to compromise the bond strength and evaluation of the degradation process to adhesive interfaces. However, after storage, an increase adhesive failure was noticed, despite the higher prevalence of mixed failures still have been found in all of the analyzed groups. This finding in our study may be associated with hydrolytic degradation of the adhesive interface (Prado et al., 2018). Aging process affects negatively the adhesive interface according to a study that submitted samples for thermocycling at 5000 thermal cycles, which acts on the reduction of bond strength values (Tribst et al., 2018), or when samples are submitted to a year storage period of aging, increase of the adhesive failure values occur, especially on self-etched treatment specimens (Murillo-Gómez \& De Goes, 2019).

Our data indicated that, considering the limitations of this in vitro study, especially in relation to the simulation of the aging procedure may not reflect a clinical condition and the dynamic degradation process. Considering such limitation, the self-etching ceramic primer may be recommended for surface treatment to glass ceramic, considering that the bond strength of self-etching silane primer showed similar performance to the conventional treatment. However, further clinical investigations are required to assess the bonding stability after simulation to a critical scenario.

\section{Conclusion}

The self-etching silane primer provided a similar ceramic/cement bond strength to HF etching and silane application in both analyses, immediate and after 90 days of aging. Morphological alterations on the ceramic surface were lower by selfetching silane primer in comparison to HF etching. Mixed failures were more prevalent among all the groups.

\section{References}

Cardenas, A. F. M., Quintero-Calderon, A. S., Siqueira, F. S. F., Campos, V. S., Wendlinger, M., Pulido-Mora, C. A., \& Loguercio, A. D. (2019). Do Different Application Modes Improve the Bonding Performance of Self-etching Ceramic Primer to Lithium Disilicate and Feldspathic Ceramics? J Adhes Dent, 21(4), 319-327. 10.3290/j.jad.a42929

Choi, Y. S., Kang, K. H., \& Att, W. (2020). Evaluation of the response of esthetic restorative materials to ultraviolet aging. J Prosthet Dent. 10.1016/j.prosdent.2020.09.007

El-Damanhoury, H. M., \& Gaintantzopoulou, M. D. (2018). Self-etching ceramic primer versus hydrofluoric acid etching: Etching efficacy and bonding performance. J Prosthodont Res, 62(1), 75-83. 10.1016/j.jpor.2017.06.002

El-Damanhoury, H. M., N, A. E., Sheela, S., \& Gaintantzopoulou, M. D. (2020). Adhesive luting to hybrid ceramic and resin composite CAD/CAM Blocks:Er:YAG Laser versus chemical etching and micro-abrasion pretreatment. J Prosthodont Res. 10.2186/jpr.JPOR_2020_50

Gracis, S., Thompson, V. P., Ferencz, J. L., Silva, N. R., \& Bonfante, E. A. (2015). A new classification system for all-ceramic and ceramic-like restorative materials. Int J Prosthodont, 28(3), 227-235. 10.11607/ijp.4244

Kim, S. H., Choi, Y. S., Kang, K. H., \& Att, W. (2021). Effects of thermal and mechanical cycling on the mechanical strength and surface properties of dental CAD-CAM restorative materials. J Prosthet Dent. 10.1016/j.prosdent.2020.11.014 
Kollmuss, M., Kist, S., Goeke, J. E., Hickel, R., \& Huth, K. C. (2016). Comparison of chairside and laboratory CAD/CAM to conventional produced allceramic crowns regarding morphology, occlusion, and aesthetics. Clin Oral Investig, 20(4), 791-797. 10.1007/s00784-015-1554-9

Lopes, G. C., Perdigão, J., Baptista, D., \& Ballarin, A. (2019). Does a Self-etching Ceramic Primer Improve Bonding to Lithium Disilicate Ceramics? Bond Strengths and FESEM Analyses. Oper Dent, 44(2), 210-218. 10.2341/17-355-1

Lung, C. Y., \& Matinlinna, J. P. (2012). Aspects of silane coupling agents and surface conditioning in dentistry: an overview. Dent Mater, 28(5), 467-477. 10.1016/j.dental.2012.02.009

Matinlinna, J. P., Lung, C. Y. K., \& Tsoi, J. K. H. (2018). Silane adhesion mechanism in dental applications and surface treatments: A review. Dent Mater, 34(1), 13-28. 10.1016/j.dental.2017.09.002

Murillo-Gómez, F., Palma-Dibb, R. G., \& De Goes, M. F. (2018). Effect of acid etching on tridimensional microstructure of etchable CAD/CAM materials. Dent Mater, 34(6), 944-955. 10.1016/j.dental.2018.03.013

Murillo-Gómez, F., \& De Goes, M. F. (2019). Bonding effectiveness of tooth-colored materials to resin cement provided by self-etching silane primer after short- and long-term storage. J Prosthet Dent, 121(4), 713.e711-713.e718. 10.1016/j.prosdent.2018.12.018

Naves, L. Z., Soares, C. J., Moraes, R. R., Gonçalves, L. S., Sinhoreti, M. A., \& Correr-Sobrinho, L. (2010). Surface/interface morphology and bond strength to glass ceramic etched for different periods. Oper Dent, 35(4), 420-427. 10.2341/09-152-1

Prado, M., Prochnow, C., Marchionatti, A. M. E., Baldissara, P., Valandro, L. F., \& Wandscher, V. F. (2018). Ceramic Surface Treatment with a Singlecomponent Primer: Resin Adhesion to Glass Ceramics. J Adhes Dent, 20(2), 99-105. 10.3290/j.jad.a40303

Ramakrishnaiah, R., Alkheraif, A. A., Divakar, D. D., Matinlinna, J. P., \& Vallittu, P. K. (2016). The Effect of Hydrofluoric Acid Etching Duration on the Surface Micromorphology, Roughness, and Wettability of Dental Ceramics. Int J Mol Sci, 17(6). 10.3390/ijms17060822

Ritzberger, C., Schweiger, M., \& Höland, W. (2016). Principles of crystal phase formation in Ivoclar Vivadent glass-ceramics for dental restorations. Journal of Non-Crystalline Solids, 432, 137-142. https://doi.org/10.1016/j.jnoncrysol.2015.04.034

Sen, N., \& Us, Y. O. (2018). Mechanical and optical properties of monolithic CAD-CAM restorative materials. J Prosthet Dent, 119(4), 593-599. 10.1016/j.prosdent.2017.06.012

Sinthuprasirt, P., van Noort, R., Moorehead, R., \& Pollington, S. (2015). Evaluation of a novel multiple phase veneering ceramic. Dent Mater, 31(4), 443-452. 10.1016/j.dental.2015.01.012

Tribst, J., Anami, L. C., Özcan, M., Bottino, M. A., Melo, R. M., \& Saavedra, G. (2018). Self-etching Primers vs Acid Conditioning: Impact on Bond Strength Between Ceramics and Resin Cement. Oper Dent, 43(4), 372-379. 10.2341/16-348-1

Venturini, A. B., Prochnow, C., Rambo, D., Gundel, A., \& Valandro, L. F. (2015). Effect of Hydrofluoric Acid Concentration on Resin Adhesion to a Feldspathic Ceramic. J Adhes Dent, 17(4), 313-320. 10.3290/j.jad.a34592

Yoshihara, K., Nagaoka, N., Maruo, Y., Nishigawa, G., Yoshida, Y., \& Van Meerbeek, B. (2020). Silane-coupling effect of a silane-containing self-adhesive composite cement. Dent Mater, 36(7), 914-926. 10.1016/j.dental.2020.04.014

Özcan, M., \& Volpato, C. A. (2015). Surface Conditioning Protocol for the Adhesion of Resin-based Materials to Glassy Matrix Ceramics: How to Condition and Why? J Adhes Dent, 17(3), 292-293. 10.3290/j.jad.a34590 